\title{
Fabrication and Characterization of Well-Dispersed and Highly Stable PtRu Nanoparticles on Carbon Mesoporous Material for Applications in Direct Methanol Fuel Cell
}

\author{
Shou-Heng Liu, ${ }^{\dagger}$ Wen-Yueh Yu, ${ }^{\ddagger}$ Ching-Hsiang Chen, ${ }^{\S}$ An-Ya Lo, ${ }^{\dagger}$ Bing-Joe Hwang, ${ }^{\S}$ \\ Shu-Hua Chien, ${ }^{* \perp}$ and Shang-Bin Liu ${ }^{*} \dagger$ \\ Institute of Atomic and Molecular Sciences, Academia Sinica, Taipei 10617, Taiwan, Institute of \\ Chemistry, Academia Sinica, Taipei 11529, Taiwan, and Department of Chemistry, National Taiwan \\ University, Taipei 10617, Taiwan, and Department of Chemical Engineering, National Taiwan University \\ of Science and Technology, Taipei 10617, Taiwan
}

Received September 27, 2007. Revised Manuscript Received November 20, 2007

\begin{abstract}
Well-dispersed, highly stable PtRu nanoparticles of ca. 2-3 nm on carbon mesoporous materials (PtRuCMMs) were synthesized directly using SBA-15 mesoporous silica as the template, furfuryl alcohol and trimethylbenzene as the primary carbon source, and platinum and ruthenium acetylacetonates as the cofeeding metal and carbon precursors. Results obtained from X-ray diffraction and X-ray photoelectron spectroscopy show that the Pt metal in the PtRu-CMMs was present in the form of a face-centered cubic (fcc) crystalline structure and the alloyed PtRu nanoparticles were composed mainly of $\mathrm{Ru}$ oxides, $\mathrm{Ru}(0)$, and $\mathrm{Pt}(0)$ metals. Further studies by X-ray absorption spectroscopy confirmed that a highly alloyed state of the PtRu nanoparticles is responsible for the superior electrocatalytic performance observed for the $\mathrm{PtRu}-\mathrm{CMMs}$, as compared to typical commercial electrocatalysts. The $\mathrm{Pt}_{50} \mathrm{Ru}_{50}-\mathrm{CMM}$ sample was found to possess the best electrocatalytic performance and long-term durability and should appeal to direct methanol fuel cell applications as anodic electrodecatalyst.
\end{abstract}

\section{Introduction}

Direct methanol fuel cell (DMFC) is a promising portable power source because of its merits, such as suitable power range for small electronic devices, high energy efficiency, and ambient operating conditions. ${ }^{1-7}$ To realize this potential for commercial applications, it is desirable to develop DMFCs and polymer electrolyte membrane fuel cells (PEMFCs) that are cost-effective, have low power loss, and possess high electrocatalytic activities and long-term durability. As such, many crucial issues remain as major challenges in the development of DMFCs and PEMFCs, in particular, the

* Corresponding author. Tel.: 886-2-23668230. Fax: 886-2-23620200. E-mail sbliu@ sinica.edu.tw. Address: Institute of Atomic and Molecular Sciences, P.O. Box 23-166, Taipei 10617, Taiwan, Republic of China.

Institute of Atomic and Molecular Sciences, Academia Sinica.

Institute of Chemistry, Academia Sinica.

$\S$ Department of Chemical Engineering, National Taiwan University of Science and Technology.

${ }^{\perp}$ Department of Chemistry, National Taiwan University.

(1) Liu, H.; Song, C.; Zhang, L.; Zhang, J.; Wang, H.; Wilkinson, D. P. J. Power Sources 2006, 155, 95.

(2) Lee, Y. H.; Lee, G.; Shim, J. H.; Huang, S.; Kwak, J.; Lee, K.; Song, H.; Park, J. T. Chem. Mater. 2006, 18, 4209.

(3) Wang, K. W.; Huang, S. Y.; Yeh, C. T. J. Phys. Chem. C 2007, 111, 5096.

(4) Wasmus, S.; Küver, A. J. Electroanal. Chem. 1999, 461, 14.

(5) Arico, A. S.; Srinivasan, S.; Antonucci, V. Fuel Cells 2001, 2, 133.

(6) (a) Lebedeva, N. P.; Janssen, G. J. M. Electrochem. Acta 2005, 51, 29. (b) Chen, W. M.; Sun, G. Q.; Liang, Z. X.; Mao, Q.; Li, H. Q.; Wang, G. X.; Xin, Q.; Chang, H.; Pak, C. H.; Seung, D. J. Power Sources 2006, 160, 933.

(7) Su, F.; Zeng, J.; Bao, X.; Yu, Y.; Lee, J. Y.; Zhao, X. S. Chem. Mater 2005, 17, 3960 .

(8) (a) Carrette, L.; Friedrich, K. A.; Stimming, U. ChemPhysChem 2000, 1, 162. (b) Mehta, V.; Copper, J. S. J. Power Sources 2003, 114, 32. (c) Chang, H.; Joo, S. H.; Pak, C. J. Mater. Chem. 2007, 17, 3078. developments of high-performance proton-exchange membrane and electrocatalyst materials, and related membrane electrode assembly (MEA). ${ }^{8}$

In terms of material development of electrodecatalysts for fuel cells, the prerequisites for their performances and practical applications include: (i) cost-down effectiveness, (ii) desirable electrical conductivity, (iii) fast reactant/product mobility (diffusion), (iv) high electrocatalytic activity, and (v) long-term stability. The first three mainly involve lowering the noble metals loading and the properties of the catalyst-supports, whereas the last two perquisites are closely related to the dispersion and alloying of the noble metals and the overall performance of the supported catalysts. Longterm operation of fuel cells normally leads to dissolution and/ or agglomeration of noble metal particles and thus degradation of the electrocatalysts. For DMFC and PEMFC applications, the effects of cathodic potential on the degradation of electrocatalysts have been widely investigated. ${ }^{9-11}$ However, relatively few studies on the anodic electrocatalysts, which have a much lower potential than the cathode, can be found. Carbon supported PtRu (PtRu/C) catalysts, which are pertinent to DMFC applications as anodic elec-

(9) (a) Colón-Mercado, H. R.; Kim, H.; Popov, B. N. Electrochem. Commun. 2004, 6, 795. (b) Antolini, E.; Salgado, J. R. C.; Gonzalez, E. R. J. Power Sources 2006, 160, 957. (c) Shao, Y. Y.; Yin, G. P.; Gao, Y. Z.; Shi, P. F. J. Electrochem. Soc. 2006, 153, A1093.

(10) (a) Colón-Mercado, H. R.; Popov, B. N. J. Power Sources 2006, 155, 253. (b) Seo, S. J.; Joh, H. I.; Kim, H. T.; Moon, S. H. J. Power Sources 2006, 163, 403.

(11) (a) Yup, P.; Pemberton, M.; Plasse, P. J. Power Sources 2005, 144, 11. (b) Koh, S.; Leisch, J.; Toney, M. F.; Strasser, P. J. Phys. Chem. C 2007, 111, 3744. 
trocatalysts, have been extensively studied because of their superior electrocatalytic activities for methanol oxidation and excellent ability for CO tolerance. ${ }^{6}$ Nonetheless, severe ruthenium dissolution and cross-over through the polyelectrolyte membrane (from anode to cathode) were observed for $\mathrm{PtRu} / \mathrm{C}$ anodic catalysts during long-term DMFC operations. ${ }^{6 b, 12}$ Thus, further investigations on the stability of the supported PtRu electrocatalyst under anode potential of DMFC remain as an urgent task. Likewise, the activity of anodic electrocatalysts, which depends strongly on the properties of the PtRu metals, including their particle size, ${ }^{13}$ shape, ${ }^{14}$ dispersion, and extent of alloying, ${ }^{15}$ are also of major consideration. There are several conventional techniques for embedding PtRu nanoparticles on porous supports, including impregnation, ${ }^{7,16}$ colloidal, ${ }^{17}$ or microemulsion method. ${ }^{18}$ However, these methods normally lead to an uncontrolled growth of the metal size and shape of particles. For example, the colloidal method is complex and time-consuming, and tends to result in undesirable loss of the noble metals.

In this paper, we report on a novel procedure, based on the pyrolysis of carbon, $\mathrm{Pt}$, and $\mathrm{Ru}$ precursors in SBA-15 mesoporous silica, to fabricate a bifunctional PtRu-carbon nanocomposite that possesses highly stable and welldispersed PtRu nanoparticles on ordered carbon mesoporous materials (CMMs) that are suitable for use as anodic electrocatalysts in DMFCs/PEMFCs.

\section{Experimental Section}

Catalyst Preparation. SBA-15 mesoporous silica was synthesized according to the procedure reported by Zhao et al. ${ }^{19}$ Subsequent direct replication of SBA-15 material into bifunctional $\mathrm{PtRu}-\mathrm{CMMs}$ with various relative noble metal loading was accomplished by adopting a strategy analogous to that for the preparation of monometal Pt-CMMs reported earlier. ${ }^{20}$ In this case, however, ca. $0.5 \mathrm{~g}$ of calcined SBA-15 was first dehydrated at 673 $\mathrm{K}$ for $4 \mathrm{~h}$ under a vacuum while various amounts of platinum acetylacetonate $\left(\mathrm{Pt}\left(\mathrm{CH}\left(\mathrm{COCH}_{3}\right)_{2}\right)_{2}\right)$, denoted as $\mathrm{Pt}(\mathrm{acac})_{2}(98 \%$, Acros)) and ruthenium acetylacetonate $\left(\mathrm{Ru}\left(\mathrm{CH}\left(\mathrm{COCH}_{3}\right)_{2}\right)_{3}\right)$, de-

(12) (a) Piela, P.; Eickes, C.; Brosha, E.; Garzon, F.; Zelenay, P. J. Electrochem. Soc. 2004, 151, A2053. (b) Taniguchi, A.; Akita, T.; Yasuda, K.; Miyazaki, Y. J. Power Sources 2004, 130, 42.

(13) Bergamaski, K.; Pinheiro, A. L. N.; Teixeira-Neto, E.; Nart, F. C. J. Phys. Chem. B 2006, 110, 19271.

(14) (a) Teng, X. W.; Maksimuk, S.; Frommer, S.; Yang, H. Chem. Mater. 2007, 19, 36. (b) Tian, N.; Zhou, Z. Y.; Sun, S. G.; Ding, Y.; Wang, Z. L. Science 2007, 316, 732.

(15) Nitani, H.; Nakagawa, T.; Daimon, H.; Kurobe, Y.; Ono, T.; Honda, Y.; Koizumi, A.; Seino, S.; Yamamoto, T. A. Appl. Catal., A 2007, 326, 194.

(16) (a) Ding, J.; Chan, K. Y.; Ren, J.; Xiao, F. S. Electrochim. Acta 2005, 50, 3131. (b) Raghuveer, V.; Manthiram, A. Electrochem. Solid-State Lett. 2004, 7, A336. (c) Raghuveer, V.; Manthiram, A. J. Electrochem. Soc. 2005, 152, A1504. (d) Guo, J. W.; Zhao, T. S.; Prabhuram, J.; Chen, R.; Wong, C. W. Electrochim. Acta 2005, 51, 754.

(17) (a) Bensebaa, F.; Patrito, N.; Page, Y. L.; Ecuyer, P. L.; Wang, D. J. Mater. Chem. 2004, 14, 3378. (b) Xue, X.; Lu, T.; Liu, C.; Xing, W. Chem. Commun. 2005, 1601. (c) Liu, Z. F.; Ada, E. T.; Shamsuzzoha, M.; Thompson, G. B.; Nikles, D. E. Chem. Mater. 2006, 18, 4946.

(18) (a) Zhang, X.; Chan, K.-Y. Chem. Mater. 2003, 15, 451. (b) Rojas, S.; Garcia, F. J.; Jaras, S.; Huerta, M. V.; Fierro, J. L. F.; Boutonnet, M. Appl. Catal., A 2005, 285, 24. (c) Tu, H. C.; Wang, W. L.; Wan, C. C.; Wang, Y. Y. J. Phys. Chem. B 2006, 110, 15988. (d) Kim, M.; Hwang, S.; Yu, J. S. J. Mater. Chem. 2007, 17, 1656.

(19) Zhao, D.; Feng, J.; Huo, Q.; Melosh, N.; Fredrickson, G. H.; Chmelka, B. F.; Stucky, G. D. Science 1998, 279, 548.

(20) Liu, S. H.; Lu, R. F.; Huang, S. J.; Lo, A. Y.; Chien, S. H.; Liu, S. B. Chem. Commun. 2006, 3435. noted as $\mathrm{Ru}(\mathrm{acac})_{3}(97 \%$, Acros) were codispersed in furfuryl alcohol (FA; 98\%, Acros) and trimethylbenzene (TMB; 98\%, Acros) under ultrasonication. Oxalic acid (98\%, Acros) was used as the acid catalysts for polymerization of FA and TMB. The mixture solution was then infiltrated in SBA-15 at room temperature ( $298 \mathrm{~K}$ ) by an incipient wetness impregnation method, followed by polymerization at $333 \mathrm{~K}$ and then $353 \mathrm{~K}$, each for $16 \mathrm{~h}$ under air. The resulting composite was treated at $423 \mathrm{~K}$ for $3 \mathrm{~h}$ and ramped to $573 \mathrm{~K}$ with a heating rate of $1 \mathrm{~K} / \mathrm{min}$. The temperature was then increased to $1073 \mathrm{~K}$ with a heating rate of $5 \mathrm{~K} / \mathrm{min}$ and maintained at that temperature for $4 \mathrm{~h}$. The above carbonization procedure was performed under a vacuum. Finally, the resultant black powders were leached with HF (1 wt \%) aqueous solution for at least $24 \mathrm{~h}$ to remove the silica template, washed with distilled water and alcohol, and then dried at $373 \mathrm{~K}$ to obtain the PtRu-CMMs.

Characterization Methods. X-ray diffraction (XRD) patterns of all samples were recorded on a PANalytical (X'Pert PRO) instrument using $\mathrm{Cu} \mathrm{K} \alpha$ radiation $(\lambda=0.1541 \mathrm{~nm})$. The compositions of various PtRu-CMM catalysts were measured by energydispersive X-ray analysis (EDX, JEOL JEM-2100F). X-ray photoelectron spectra (XPS) were acquired through an energy analyzer with a constant pass energy of $20 \mathrm{eV}$ followed by irradiating a sample pellet (6 $\mathrm{mm}$ in diameter) with a monochromatic $\mathrm{Al} \mathrm{K} \alpha$ $(1486.6 \mathrm{eV}) \mathrm{X}$-ray under ultrahigh vacuum conditions $\left(1 \times 10^{-10}\right.$ Torr). Nitrogen adsorption isotherms were measured at $77 \mathrm{~K}$ on a Quantachrome Autosorb-1 volumetric adsorption analyzer. For transmission electron microscopy (TEM) experiments, samples were first suspended in acetone ( $99.9 \mathrm{vol} \%$ ) by ultrasonication, followed by deposition of the suspension on a lacey carbon grid, then the TEM images were obtained at room temperature using an electron microscope (JEOL JEM-2100F) that has a field-emission gun at an acceleration voltage of $200 \mathrm{kV}$. The $\mathrm{Pt}_{\mathrm{III}}$-edge and Ru K-edge XANES and EXAFS spectra of the PtRu-CMMs were collected at the Wiggler beamlines $01 \mathrm{C} 1$ of the Synchrotron Radiation Research Center (SRRC) in Taiwan. A Si(111) double-crystal monochromator was used for selection of energy with a resolution of $2 \times 10^{-4}$ $(\mathrm{eV} / \mathrm{eV})$. Two gas-filled ionization chambers were used in series to measure the intensities of the incident beam $\left(I_{\mathrm{o}}\right)$ and the beam transmitted through the sample $\left(I_{\mathrm{t}}\right)$ on a reference foil $\left(I_{\mathrm{r}}\right)$. A third ion chamber was used in conjunction with a reference sample $(\mathrm{Pt}$ foil or $\mathrm{Ru}$ powder for $\mathrm{Pt} \mathrm{L}_{\mathrm{III}}$-edge or $\mathrm{Ru} \mathrm{K}$-edge measurements, respectively). Standard procedures were employed to analyze the spectra acquired by X-ray absorption spectroscopy (XAS). Each EXAFS function $(\chi)$ was obtained by subtracting the postedge background from the overall absorption and then normalized with respect to the edge jump step. Subsequently, $k^{3}$-weighted $\chi(k)$ spectra in the $k$-space, ranging, respectively, from 3.6 to $12.5 \AA^{-1}$ for the Pt $\mathrm{L}_{\mathrm{III}}$-edge and from 3.6 to $11.6 \AA^{-1}$ for the Ru K-edge, were Fourier transformed (FT) to the $r$-space to separate the EXAFS contributions from different coordination shells. A nonlinear leastsquares algorithm was applied to fit (without phase correction) the EXAFS spectra in the $r$-space between 1.7 and $3.2 \AA$ for $\mathrm{Pt}$ and between 1.5 and $3.2 \AA$ for $\mathrm{Ru}$, respectively. The $\mathrm{Pt}-\mathrm{Ru}$ reference file was determined by theoretical calculation. All computer programs were implemented in an UWXAFS 3.0 package $^{21}$ with the backscattering amplitude and the phase shift for the specific atom pairs being theoretically calculated using the FEFF7 code. ${ }^{22}$

Electrochemical Measurements. Electrocatalytic activity measurements of various PtRu-CMMs and a commercial JohnsonMatthey PtRu/C sample (20 wt \% Pt and $10 \mathrm{wt} \% \mathrm{Ru}$ on activated

(21) Stern, F. A.; Newville, M.; Ravel, B.; Yacoby, Y.; Haskel, D. Physica B 1995, 208-209, 117.

(22) Zabinsky, S.; Rehr, J. J.; Ankudinov, A. L.; Albers, R. C.; Eller, M. J. Phys. Rev. B 1995, 52, 2995. 

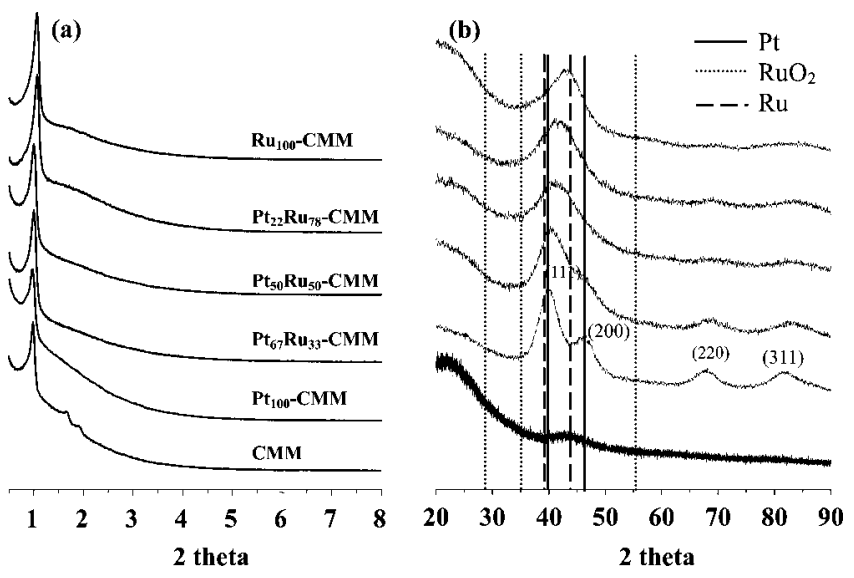

Figure 1. (a) Small- and (b) large-angle powder XRD patterns of CMM and Pt-, PtRu-, and Ru-CMM samples.

carbon Vulcan $\mathrm{XC}-72$, hereafter denoted as JM-PtRu/C) were performed on a galvanostat/potentiostat (Autolab, PGSTAT30) at a scanning rate of $10 \mathrm{mV} / \mathrm{s}$. The glossy carbon thin-film electrode was prepared by the following steps: first, ca. $5 \mathrm{mg}$ of PtRu-loaded carbon sample was added into $2.5 \mathrm{~mL}$ of deionized water, followed by ultrasonic treatment for $0.5 \mathrm{~h}$. Next, ca. $20 \mu \mathrm{L}$ of the resultant suspension mixture was withdrawn and injected onto the glassy carbon electrode, followed by drying in air at $333 \mathrm{~K}$ for $1 \mathrm{~h}$. Finally, $20 \mu \mathrm{L}$ of $1 \%$ Nafion (DuPont) solution was added as a binder under a $\mathrm{N}_{2}$ environment. Electrooxidation of $\mathrm{MeOH}$ was carried out with an electrolyte of $0.5 \mathrm{M} \mathrm{H}_{2} \mathrm{SO}_{4}$ and $1 \mathrm{M} \mathrm{MeOH}$ between -0.2 and $1.0 \mathrm{~V}$ at room temperature. Prior to each cyclic voltammetry (CV) measurement, the electrolytic solution was purged with high-purity $\mathrm{N}_{2}(99.9 \%)$ for at least $0.5 \mathrm{~h}$ to remove the dissolved oxygen; subsequently, the experiment was conducted under purging $\mathrm{N}_{2}$ condition.

\section{Results and Discussion}

As shown in Figure 1a, the small-angle XRD patterns observed for various Pt-, PtRu-, and Ru-CMMs all reveal a main (100) diffraction peak at $2 \theta=1.0^{\circ}$, indicating the existence of a mesoporous structure with a long-range order and a two-dimensional hexagonal symmetry similar to that of the carbon mesoporous material CMK- $3{ }^{23}$ It is noted that although a slight decrease in the unit-cell parameter $(a)$ of the 2D hexagonal lattice of CMMs was found (Table 1), variations in $\mathrm{Pt} / \mathrm{Ru}$ loading have a negligible effect on the overall structure and the physical properties of the catalyst. In particular, the large-angle XRD pattern of $\mathrm{Pt}_{100}$-CMM (Figure 1b) shows distinct (111), (200), (220), and (311) diffraction peaks at $2 \theta=39.8,46.2,67.8$, and $81.3^{\circ}$, respectively, indicating that the Pt metal particle possesses a face-centered cubic (fcc) structure. Upon increasing the $\mathrm{Ru}$ loading, all the PtRu-CMMs exhibit diffraction patterns that are similar to that of the Pt-CMM catalyst, except that the $2 \theta$ values of their main peak was slightly shifted toward a higher value, suggesting a reduction of their respective lattice constants $\left(a_{\mathrm{fcc}}\right.$; Table 1$)$ and hence an increasing extent of the alloying of the Pt and $\mathrm{Ru}$ particles in the CMM

(23) Jun, S.; Joo, S. H.; Ryoo, R.; Kruk, M.; Jaroniec, M.; Liu, Z.; Ohsuna, T.; Terasaki, O. J. Am. Chem. Soc. 2000, 122, 10712. (b) Joo, S. H.; Ryoo, R.; Kruk, M.; Jaroniec, M. Chem. Commun. 2001, 349. (c) Joo, S. H.; Ryoo, R.; Kruk, M.; Jaroniec, M. J. Phys. Chem. B 2002, 106, 4640. (d) Joo, S. H.; Choi, S. J.; Oh, I.; Kwak, J.; Liu, Z.; Terasaki, O.; Ryoo, R. Nature 2001, 412, 169. supports. ${ }^{24}$ Increasing substitution of Pt by the smaller Ru atoms in PtRu-CMMs therefore result in progressive contraction of the fcc lattice of the alloy nanoparticles, in accordance with the progressive decrease in the average metal particle size $\left(D_{\mathrm{p}}\right)$ deduced from the Scherrer formula (Table 1$){ }^{25}$ The peak positions anticipated for the characteristic features of $\mathrm{Pt}, \mathrm{Ru}$, and $\mathrm{RuO}_{2}$ are also indicated in Figure 1b. Clearly, the XRD pattern observed for $\mathrm{Ru}_{100}-\mathrm{CMM}$ did not match with the typical hexagonal close-packed (hcp) structure possessed by pure $\mathrm{Ru}$ and $\mathrm{RuO}_{2}$, suggesting that some ruthenium oxides may be present as an amorphous state in PtRu-CMMs and $\mathrm{Ru}_{100}-\mathrm{CMM}$. Nonetheless, the absence of the hep phase of Ru in PtRu-CMMs indicates the formation of PtRu alloys in the supported catalysts.

All $\mathrm{N}_{2}$ adsorption/desorption curves obtained from various PtRu-CMM samples showed the typical type-IV isotherm with a well defined hysteresis loop (see the Supporting Information, Figure S1a). Accordingly, the BET surface area, pore volume, and pore size distribution (by BJH method) of various samples can be derived (Table 1). In brief, all supported catalyst samples were found to possess a high surface area $\left(>1,000 \mathrm{~m}^{2} / \mathrm{g}\right)$ and a uniform pore size distribution $(2.9 \mathrm{~nm}$; see the Supporting Information, Figure S1b). That the average pore size observed for various PtRu-CMMs is comparable to the pure CMM (i.e., CMK-3) is due to the fact that they arise from the skeleton of the SBA-15 mesoporous silica template, which was subsequently removed by acid washing after carbonization, whereas the surface areas and pore volumes of $\mathrm{Pt}, \mathrm{Ru}$ and $\mathrm{PtRu}-\mathrm{CMMs}$, being smaller compared to pure CMM, can be ascribed to partial exposure of the PtRu nanoparticles (after silica template removal) and the higher density of the alloyed metal than CMM. On the other hand, the decrease in surface areas and pore volumes observed for the PtRu- and Ru-CMM catalysts compared to Pt-CMM are attributable to a progressive decrease in the size of the PtRu alloy nanoparticles with increasing Ru loading, which is in line with the XRD results discussed earlier. The dispersions $(\Delta)$ of the PtRu nanoparticles in various samples obtained from $\mathrm{H}_{2}$ chemisorption studies are also depicted in Table 1. Alternatively, the metal particle size $\left(D_{\mathrm{c}}\right)$ of the $\mathrm{Pt}_{100}-\mathrm{CMM}$ and $\mathrm{Ru}_{100}$-CMM samples can also be derived from $\mathrm{H}_{2}$ chemisorption data based on an empirical equation, ${ }^{26} D_{\mathrm{c}}=1.08 \Delta^{-1}$. Accordingly, a $D_{\mathrm{c}}$ value of 3.6 and $2.8 \mathrm{~nm}$ was deduced for $\mathrm{Pt}_{100}-\mathrm{CMM}$ and $\mathrm{Ru}_{100}$-CMM, respectively. That the $D_{\mathrm{c}}$ values so obtained are larger than the $D_{\mathrm{p}}$ values derived from the XRD data (Table 1) may be attributed to the fact that part of the metal surfaces were embedded in the CMM and hence were less accessible to $\mathrm{H}_{2}$, as evidenced by the TEM results (see below).

The structure and metal dispersion of various PtRu-CMM samples were further verified by TEM measurements. All the TEM images displayed in Figure 2 and the Supporting Information, Figure S2, for various PtRu-CMMs exhibit a

(24) Vegard, L. Z. Phys. 1921, 5, 17.

(25) Guo, J. W.; Zhao, T. S.; Prabhuram, J.; Chen, R.; Wong, C. W. Electrochim. Acta 2005, 51, 754.

(26) Ubago-Pérez, R.; Carrasco-Marín, F.; Moreno-Castilla, C. Appl. Catal., A 2004, 275, 119. 
Table 1. Physical Properties of Pure CMM and Pt-, PtRu-, and Ru-CMM Samples

\begin{tabular}{|c|c|c|c|c|c|c|c|c|}
\hline sample & $\mathrm{Pt}: \mathrm{Ru}^{a}$ & $a^{b}(\mathrm{~nm})$ & $S^{c}\left(\mathrm{~m}^{2} / \mathrm{g}\right)$ & $d^{d}(\mathrm{~nm})$ & $V^{e}\left(\mathrm{~cm}^{3} / \mathrm{g}\right)$ & $\Delta^{f}(\%)$ & $D_{\mathrm{p}}{ }^{g}(\mathrm{~nm})$ & $a_{\mathrm{fcc}}^{h}(\mathrm{~nm})$ \\
\hline CMM (CMK-3) & & 10.5 & 1632 & 2.9 & 1.25 & & & \\
\hline $\mathrm{Pt}_{100}-\mathrm{CMM}$ & $8: 0$ & 10.4 & 1095 & 2.9 & 0.78 & 30 & 3.0 & 0.3904 \\
\hline $\mathrm{Pt}_{67} \mathrm{Ru}_{33}-\mathrm{CMM}$ & $8: 2$ & 10.2 & 1085 & 2.9 & 0.80 & 37 & 2.4 & 0.3856 \\
\hline $\mathrm{Pt}_{22} \mathrm{Ru}_{78}-\mathrm{CMM}$ & $8: 14$ & 10.1 & 1058 & 2.9 & 0.81 & 44 & 1.8 & \\
\hline $\mathrm{Ru}_{100}-\mathrm{CMM}$ & $0: 8$ & 10.1 & 1311 & 2.9 & 0.96 & 39 & 2.0 & \\
\hline
\end{tabular}

${ }^{a}$ Metal atomic ratios (wt \%:wt\%) deduced from EDX results. ${ }^{b}$ Unit-cell parameters of the mesoporous carbon support. ${ }^{c}$ Brunauer-Emmet-Teller (BET) surface areas. ${ }^{d}$ Pore diameters calculated by the Barrett-Joyner-Halenda (BJH) method using the adsorption branches. ${ }^{e}$ Total pore volumes calculated as the amount of $\mathrm{N}_{2}$ adsorbed at a relative pressure of $0.99 .{ }^{f}$ Metal dispersions measured by $\mathrm{H}_{2}$ chemisorption at $323 \mathrm{~K} .{ }^{g}$ Average particle size deduced by Scherrer formula. ${ }^{h}$ Lattice constants of Pt and PtRu alloys deduced by Vegard's Law ${ }^{24}$ on the basis of the (220) diffraction peak in Figure 1b.

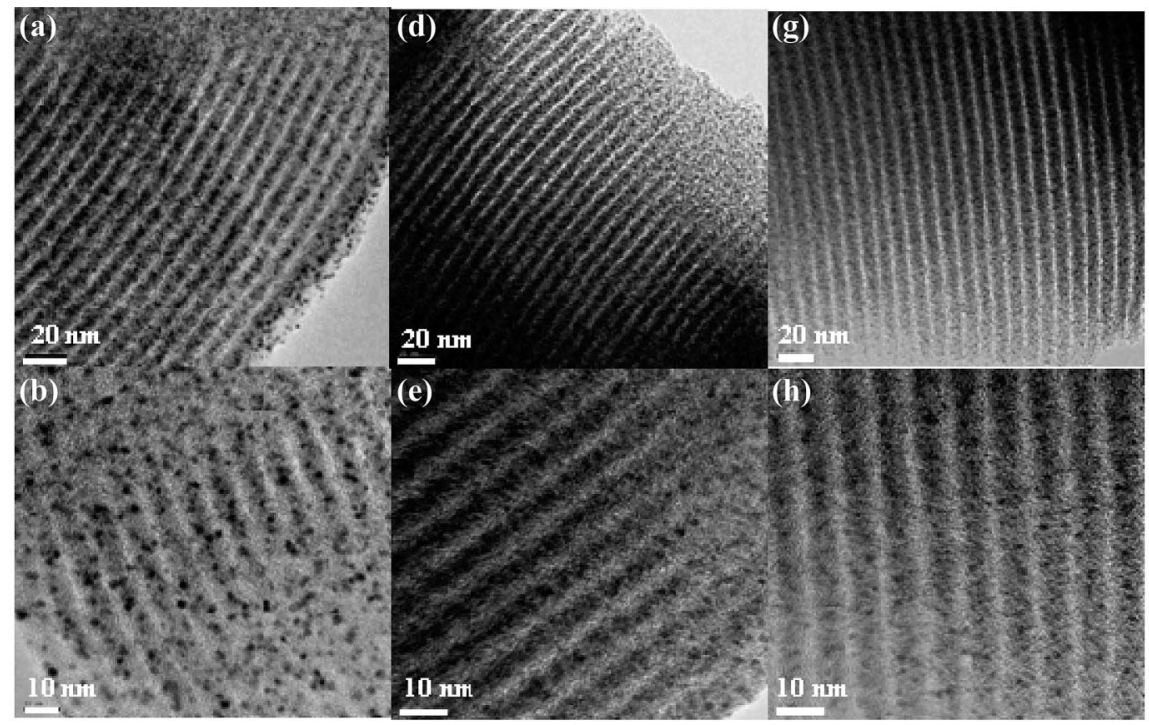

(c)

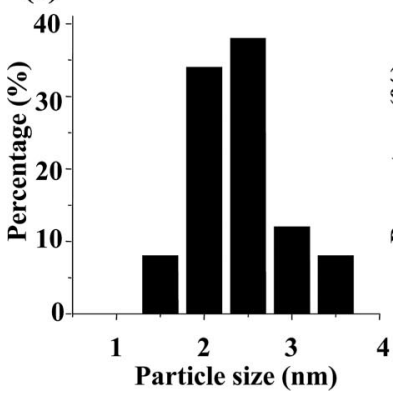

(f)

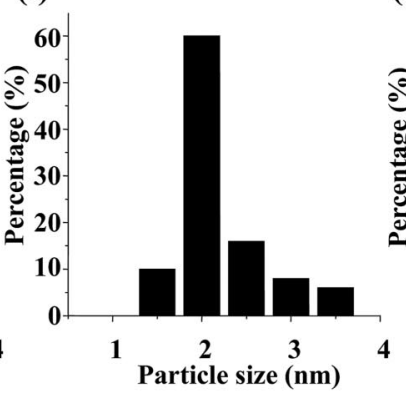

(i)

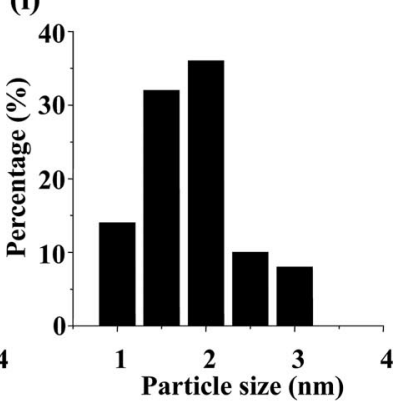

Figure 2. TEM images and histograms of metal particle size distribution of $(\mathrm{a}-\mathrm{c}) \mathrm{Pt}_{100}-\mathrm{CMM}$, $(\mathrm{d}-\mathrm{f}) \mathrm{Pt}_{50} \mathrm{Ru}_{50}-\mathrm{CMM}$, and $(\mathrm{g}-\mathrm{i}) \mathrm{Ru} \mathrm{u}_{100}-\mathrm{CMM}$.

uniform array of mesopores with a long-range order. It can be seen that for all supported Pt-CMM, PtRu-CMMs, and $\mathrm{Ru}-\mathrm{CMM}$ catalysts, monometal (Pt, Ru) and PtRu alloy particles with an average particle size of ca. $2-3 \mathrm{~nm}$ are uniformly dispersed and studded on the surface of the carbon rods. The histograms of metal particle size distribution shown in Figure 2 and the Supporting Information, Figure S2, provide additional support to the aforediscussed XRD and $\mathrm{H}_{2}$ chemisorption results.

The surface compositions and the chemical oxidation states of $\mathrm{Pt}, \mathrm{Ru}, \mathrm{C}$, and $\mathrm{O}$ in the PtRu-CMMs with various $\mathrm{Pt} / \mathrm{Ru}$ atomic ratios were characterized by XPS analysis. All the C 1s XPS spectra obtained from the PtRu-CMM samples (see the Supporting Inforamtion, Figure S3a) revealed a broad peak centered at ca. $284.5 \mathrm{eV}$, which could be attributed to the $\mathrm{sp}^{2}$ graphitic carbon species. Likewise, all the $\mathrm{O} 1 \mathrm{~s}$ spectra (see the Supporting Information, Figure S3b) show single broad peaks, indicating the existence of various oxygen species. A similar full-width half-maximum (fwhm) line width of ca. $1.1 \mathrm{eV}$ was observed in all the $\mathrm{C} 1 \mathrm{~s}$ spectra for $\mathrm{PtRu}-\mathrm{CMMs}$, suggesting the presence of less-ordered graphene layers compared to graphitized carbon black $(0.82 \mathrm{eV}) .{ }^{27}$ Again, this may be attributed to perturbation of the embedded $\mathrm{PtRu}$ alloys in the CMM frameworks. Figure 3 shows the regional $\mathrm{Pt}$ 4f and $\mathrm{Ru} 3 \mathrm{p}$ XPS spectra of various catalyst samples. Regardless of the Pt/Ru loading, the Pt 4f spectra in Figure 3a show two broad peaks, which could be deconvoluted into two pairs of doublets with the most intense peaks centering at binding energies of ca. 71.3 and $74.6 \mathrm{eV}$, respectively. These two intense peaks are attributed to $\mathrm{Pt}$ $4 \mathrm{f}_{7 / 2}$ and $\mathrm{Pt} 4 \mathrm{f}_{5 / 2}$ excitations of metallic $\operatorname{Pt}(0)$, whereas the

(27) (a) Darmstadt, H.; Roy, C.; Kaliaguine, S.; Choi, S. J.; Ryoo, R. Carbon 2002, 40, 2673. (b) Darmstadt, H.; Roy, C.; Kaliaguine, S.; Kim, T.-W.; Ryoo, R. Chem. Mater. 2003, 15, 3300. (c) Sakintuna, B.; Yürüm, Y. Ind. Eng. Chem. Res. 2005, 44, 2893. 

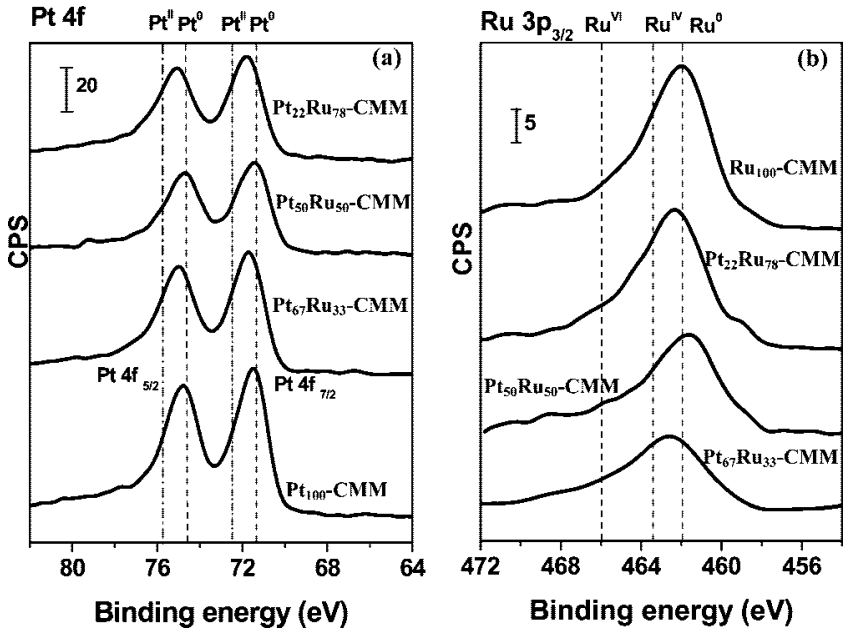

Figure 3. XPS spectra of various PtRu-CMM catalysts at (a) Pt $4 \mathrm{f}$ and (b) $\mathrm{Ru} 3 \mathrm{p}$ regions.

two weaker shoulder peaks (at 72.3 and $75.6 \mathrm{eV}$ ) are ascribed to oxidized platinum, i.e., Pt(II). On the other hand, the $\mathrm{Ru}$ $3 p_{3 / 2}$ XPS spectra (Figure $3 b$ ) could be deconvoluted into three peaks with binding energies of ca. 461.2, 462.8, and $465.5 \mathrm{eV}$ and assigned as $\mathrm{Ru}(0)$ metal, $\mathrm{Ru}(\mathrm{IV})$ (e.g., $\mathrm{RuO}_{2}$ ), and the higher oxidation states of Ru oxides, respectively. Thus, it is indicative that the surface of the PtRu nanoparticles on various PtRu-CMMs is mainly composed of $\mathrm{Ru}$ oxides, $\operatorname{Ru}(0)$, and $\operatorname{Pt}(0)$ metals. This is similar to that of $\mathrm{PtRu}$ alloys supported on activated carbon or carbon nanotubes. ${ }^{18 a, 28}$ The presence of oxygen species in Ru oxides has been suggested ${ }^{29}$ to play a synergetic role for secondary $\mathrm{CO}$ oxidation reaction, which occurs inevitably during the primary PtRu bifunctional-catalyzed direct methanol oxidation reaction under normal DMFC operations.

The species and their corresponding binding energies at the $\mathrm{Pt} 4 \mathrm{f}_{7 / 2}$ and $\mathrm{Ru} 3 \mathrm{p}_{3 / 2}$ core level regions of various PtRuCMMs can be deduced from the respective deconvoluted spectra. The results are summarized in Table 2. It is noted that the $\mathrm{Pt}$ to $\mathrm{Ru}$ atomic ratio of the PtRu-CMM catalysts determined from the XPS results tends to deviate from the nominal value anticipated from bulk compositions. This indicates that the $\mathrm{Pt}$ and $\mathrm{Ru}$ components are not uniformly distributed and that the surface of these bifunctional catalysts is more enriched with $\mathrm{Ru}$ species than those prepared by conventional postsynthesis impregnation method. Moreover, that the concentrations of $\mathrm{Pt}(0)$ and $\mathrm{Ru}(0)$ in $\mathrm{Pt}_{50} \mathrm{Ru}_{50}-\mathrm{CMM}$ are notably greater than those in $\mathrm{Pt}_{67} \mathrm{Ru}_{33}-\mathrm{CMM}$ and $\mathrm{Pt}_{22} \mathrm{Ru}_{78^{-}}$ CMM catalysts provides complementary support to its superior electrocatalytic performance during methanol oxidation (see below).

To further understand the structure and the extent of the alloying of PtRu nanoparticles in the PtRu-CMMs, we performed additional X-ray absorption spectroscopy (XAS) experiments using a synchrotron radiation light source. On

(28) (a) Bock, C.; Blakely, M.-A.; MacDougall, B. Electrochim. Acta 2005, 50, 2401. (b) Huang, S. Y.; Chang, S. M.; Yeh, C. T. J. Phys. Chem. $B$ 2006, 110, 234. (c) Liu, Z. L.; Ling, X. Y.; Guo, B.; Hong, L.; Lee, J. Y. J. Power Sources 2007, 167, 272. (d) Prabhuram, J.; Zhao, T. S.; Liang, Z. X.; Chen, R. Electrochim. Acta 2007, 52, 2649.

(29) Rolison, D. R.; Hagans, P. L.; Swider, K. E.; Long, J. W. Langmuir 1999, 15, 774 .
Table 2. Assignments, Binding Energies, and Concentrations of Pt $4 f$ and Ru 3p Species in Various Samples Obtained from XPS Results

\begin{tabular}{|c|c|c|c|c|c|}
\hline sample & species & assignment & $\mathrm{BE}^{a}$ & $\mathrm{Pt}: \mathrm{Ru}^{b}$ & concentration $^{c}$ \\
\hline \multirow[t]{2}{*}{$\mathrm{Pt}_{100}-\mathrm{CMM}$} & \multirow[t]{2}{*}{$\operatorname{Pt} 4 \mathrm{f}_{7 / 2}$} & $\operatorname{Pt}(0)$ & 71.3 & & 57 \\
\hline & & $\mathrm{Pt}(\mathrm{II})$ & 72.3 & & 43 \\
\hline \multirow[t]{5}{*}{$\mathrm{Pt}_{67} \mathrm{Ru}_{33}-\mathrm{CMM}$} & \multirow[t]{2}{*}{$\mathrm{Pt} 4 \mathrm{f}_{7 / 2}$} & $\operatorname{Pt}(0)$ & 71.6 & $38: 62$ & 56 \\
\hline & & $\mathrm{Pt}(\mathrm{II})$ & 72.6 & & 44 \\
\hline & \multirow[t]{3}{*}{$\mathrm{Ru} 3 \mathrm{P}_{3 / 2}$} & $\mathrm{Ru}(0)$ & 461.2 & & 26 \\
\hline & & $\mathrm{Ru}(\mathrm{IV})$ & 462.8 & & 40 \\
\hline & & $\mathrm{Ru}(\mathrm{VI})$ & 465.5 & & 34 \\
\hline \multirow[t]{5}{*}{$\mathrm{Pt}_{50} \mathrm{Ru}_{50}-\mathrm{CMM}$} & \multirow[t]{2}{*}{$\operatorname{Pt} 4 \mathrm{f}_{7 / 2}$} & $\operatorname{Pt}(0)$ & 71.6 & $30: 70$ & 65 \\
\hline & & $\mathrm{Pt}(\mathrm{II})$ & 72.6 & & 35 \\
\hline & \multirow[t]{3}{*}{$\mathrm{Ru} 3 \mathrm{P}_{3 / 2}$} & $\mathrm{Ru}(0)$ & 461.2 & & 54 \\
\hline & & $\mathrm{Ru}(\mathrm{IV})$ & 462.8 & & 40 \\
\hline & & $\mathrm{Ru}(\mathrm{VI})$ & 465.5 & & 6 \\
\hline \multirow[t]{5}{*}{$\mathrm{Pt}_{22} \mathrm{Ru}_{78}-\mathrm{CMM}$} & \multirow[t]{2}{*}{$\mathrm{Pt} 4 \mathrm{f}_{7 / 2}$} & $\operatorname{Pt}(0)$ & 71.6 & $24: 76$ & 55 \\
\hline & & $\operatorname{Pt}(\mathrm{II})$ & 72.6 & & 45 \\
\hline & \multirow[t]{3}{*}{$\mathrm{Ru} 3 \mathrm{P}_{3 / 2}$} & $\mathrm{Ru}(0)$ & 461.2 & & 29 \\
\hline & & $\mathrm{Ru}(\mathrm{IV})$ & 462.7 & & 51 \\
\hline & & $\mathrm{Ru}(\mathrm{VI})$ & 465.5 & & 20 \\
\hline \multirow[t]{3}{*}{$\mathrm{Ru}_{100}-\mathrm{CMM}$} & \multirow[t]{3}{*}{$\mathrm{Ru} 3 \mathrm{P}_{3 / 2}$} & $\mathrm{Ru}(0)$ & 461.2 & & 36 \\
\hline & & $\mathrm{Ru}(\mathrm{IV})$ & 462.7 & & 55 \\
\hline & & $\mathrm{Ru}(\mathrm{VI})$ & 465.5 & & 9 \\
\hline
\end{tabular}

${ }^{a}$ Binding energy (in eV). ${ }^{b}$ Atomic ratio. ${ }^{c}$ Per species (in at \%).

Table 3. Assorted EXAFS Parameters Derived from Fitting Results at the Pt $\mathrm{L}_{\mathrm{III}}$ and $\mathrm{Ru} \mathrm{K}$ Edges

\begin{tabular}{|c|c|c|c|c|c|c|}
\hline edge & shell & $N^{a}$ & $R_{\mathrm{j}}(\AA)^{b}$ & $\sigma^{2} \times 10^{-3}\left(\AA^{2}\right)^{c}$ & $\Delta E_{\mathrm{o}}(\mathrm{eV})^{d}$ & $R$ factor \\
\hline \multicolumn{7}{|c|}{$\mathrm{Pt}_{100}-\mathrm{CMM}$} \\
\hline \multirow[t]{2}{*}{ Pt $\mathrm{L}_{\mathrm{III}}$} & $\mathrm{Pt}-\mathrm{Pt}$ & 8.2 & 2.747 & 6.6 & 3.5 & 0.0023 \\
\hline & & & & \multicolumn{2}{|c|}{$\mathrm{Pt}_{67} \mathrm{Ru}_{33}-\mathrm{CMM}$} & \\
\hline \multirow[t]{2}{*}{ Pt L LIII } & $\mathrm{Pt}-\mathrm{Ru}$ & 1.1 & 2.694 & 4.5 & 5.5 & 0.0095 \\
\hline & $\mathrm{Pt}-\mathrm{Pt}$ & 4.8 & 2.710 & 6.9 & 6.2 & \\
\hline \multirow[t]{2}{*}{ Ru K } & $\mathrm{Ru}-\mathrm{Ru}$ & 4.1 & 2.642 & 6.0 & -0.2 & \\
\hline & $\mathrm{Ru}-\mathrm{Pt}$ & 1.4 & 2.694 & 4.1 & -1.8 & \\
\hline \multicolumn{7}{|c|}{$\mathrm{Pt}_{50} \mathrm{Ru}_{50}-\mathrm{CMM}$} \\
\hline \multirow[t]{2}{*}{ Pt L LIII } & $\mathrm{Pt}-\mathrm{Ru}$ & 1.4 & 2.680 & 3.8 & 4.8 & 0.0119 \\
\hline & $\mathrm{Pt}-\mathrm{Pt}$ & 3.5 & 2.691 & 5.7 & 5.5 & \\
\hline \multirow[t]{2}{*}{ Ru K } & $\mathrm{Ru}-\mathrm{Ru}$ & 4.1 & 2.637 & 6.3 & -0.6 & \\
\hline & $\mathrm{Ru}-\mathrm{Pt}$ & 0.8 & 2.680 & 4.4 & -1.5 & \\
\hline \multicolumn{7}{|c|}{$\mathrm{Pt}_{22} \mathrm{Ru}_{78}-\mathrm{CMM}$} \\
\hline \multirow[t]{2}{*}{ Pt $\mathrm{L}_{\mathrm{III}}$} & $\mathrm{Pt}-\mathrm{Ru}$ & 1.7 & 2.692 & 4.2 & 6.3 & 0.0058 \\
\hline & $\mathrm{Pt}-\mathrm{Pt}$ & 3.6 & 2.710 & 6.3 & 5.1 & \\
\hline \multirow[t]{2}{*}{ Ru K } & $\mathrm{Ru}-\mathrm{Ru}$ & 4.7 & 2.650 & 5.8 & 0.2 & \\
\hline & $\mathrm{Ru}-\mathrm{Pt}$ & 0.9 & 2.692 & 7.1 & -3.1 & \\
\hline \multicolumn{7}{|c|}{$\mathrm{Ru}_{100}-\mathrm{CMM}$} \\
\hline \multirow[t]{2}{*}{ Ru K } & $\mathrm{Ru}-\mathrm{O}$ & 2.4 & 1.782 & 1.3 & -5.7 & 0.0241 \\
\hline & $\mathrm{Ru}-\mathrm{Ru}$ & 4.3 & 2.655 & 6.8 & 0.2 & \\
\hline \multicolumn{7}{|c|}{ JM-PtRu/C } \\
\hline \multirow[t]{2}{*}{ Pt L LIII } & $\mathrm{Pt}-\mathrm{Ru}$ & 2.7 & 2.719 & 5.0 & 6.6 & 0.0050 \\
\hline & $\mathrm{Pt}-\mathrm{Pt}$ & 6.2 & 2.739 & 6.0 & 5.7 & \\
\hline \multirow[t]{2}{*}{ Ru K } & $\mathrm{Ru}-\mathrm{Ru}$ & 4.5 & 2.678 & 5.0 & 2.3 & \\
\hline & $\mathrm{Ru}-\mathrm{Pt}$ & 2.7 & 2.719 & 4.0 & 2.0 & \\
\hline
\end{tabular}

the basis of the EXAFS oscillations in the backgroundsubtracted $k^{3}$-weighted spectra recorded at the $\mathrm{Pt} \mathrm{L}_{\mathrm{III}}$-edge and Ru K-edge (see the Supporting Information, Figure S4) and their corresponding Fourier transforms (see the Supporting Information, Figure S5) observed for various PtRuCMMs, EXAFS parameters such as the coordination number $(N)$, bond distance $(R)$, Debye-Waller factor $\left(\sigma^{2}\right)$, and inner potential shift $\left(\Delta E_{\mathrm{o}}\right)$ were deduced, as listed in Table 3. At the Pt $\mathrm{L}_{\mathrm{III}}$-edge (see the Supporting Information, Figure S5a), a notable peak splitting corresponding to the first shell was observed in the region of 1.8-3.0 A. The appearance of these peaks, which arise from radiation backscattering from Pt and $\mathrm{Ru}$ neighbors, indicates the formation of PtRu alloyed 
Table 4. Structural Coordination Parameters for Various PtRu-CMM and the JM-PtRu/C Catalysts

\begin{tabular}{|c|c|c|c|c|c|}
\hline sample & $P_{\text {observed }}{ }^{a}$ & $R_{\text {observed }}^{b}$ & $\Sigma N_{\mathrm{Pt}-\mathrm{i}}{ }^{c}$ & $\sum N_{\mathrm{Ru}-\mathrm{i}}{ }^{d}$ & $Q^{e}$ \\
\hline $\mathrm{Pt}_{67} \mathrm{Ru}_{33}-\mathrm{CMM}$ & 0.19 & 0.26 & 5.9 & 5.5 & 1.07 \\
\hline $\mathrm{Pt}_{50} \mathrm{Ru}_{50}-\mathrm{CMM}$ & 0.29 & 0.17 & 4.9 & 4.9 & 1.01 \\
\hline $\mathrm{Pt}_{22} \mathrm{Ru}_{78}-\mathrm{CMM}$ & 0.32 & 0.16 & 5.3 & 5.6 & 0.94 \\
\hline JM-PtRu/C & 0.30 & 0.38 & 8.9 & 7.2 & 1.24 \\
\hline
\end{tabular}

nanoparticles. ${ }^{30,31}$ The total scattering atoms, i.e., the sum of $\mathrm{Pt}$ and $\mathrm{Ru}$ coordination numbers around the absorbing $\mathrm{Pt}$ $\left(\Sigma N_{\mathrm{Pt}-\mathrm{i}}=N_{\mathrm{Pt}-\mathrm{Pt}}+N_{\mathrm{Pt}-\mathrm{Ru}}\right)$, in $\mathrm{Pt}_{50} \mathrm{Ru}_{50}-\mathrm{CMM}$ was found to be 4.9 (Table 4), which is less than that of the commercial JM$\mathrm{PtRu} / \mathrm{C}$ catalyst $\left(\Sigma N_{\mathrm{Pt}-\mathrm{i}}=7.0\right)$. This is again in excellent agreement with the decreasing particle size of the PtRu alloy in $\mathrm{Pt}_{50} \mathrm{Ru}_{50}-\mathrm{CMM}$ observed from the aforementioned TEM and XRD studies.

The extent of alloying could be determined by quantitative analysis of the atomic distribution of PtRu nanoparticles derived from the EXAFS data listed in Table $3 .{ }^{32}$ Accordingly, the intraparticle dispersion of $\mathrm{Pt}$ and $\mathrm{Ru}$ could be evaluated by the structural coordination parameters, namely, $P_{\text {observed }}, R_{\text {observed }}, \Sigma N_{\mathrm{Pt}-\mathrm{i}}, \Sigma N_{\mathrm{Ru}-\mathrm{i}}$, and $Q$, as defined and depicted in Table 4. The total coordination number of the $\mathrm{Pt}$ and $\mathrm{Ru}$ atoms around Pt, $\Sigma N_{\mathrm{Pt-i}}$, observed for the PtRu-CMMs was found to span in the range of 4.9-5.9, whereas that around $\mathrm{Ru}, \Sigma N_{\mathrm{Ru}-\mathrm{i}}$, was found to vary within 4.9-5.6. That the $\Sigma N_{\mathrm{Pt}-\mathrm{i}}$ value obtained for the respective $\mathrm{PtRu}-\mathrm{CMM}$ catalysts is almost equal to the corresponding $\Sigma N_{\text {Ru-i }}$ value (i.e., $Q \approx$ 1 ), suggests that nearly all of the Pt and $\mathrm{Ru}$ atoms were involved in the alloying process. Thus, the $\mathrm{Pt}$ and $\mathrm{Ru}$ atoms in all the PtRu-CMM catalysts examined herein are tightly coupled through strong heterometallic bonding, leading to the formation of "heteroatomic-rich" nanoclusters. ${ }^{32}$ By comparison, that the $\Sigma N_{\mathrm{Pt}-\mathrm{i}}$ value observed for the JM-PtRu/C catalyst was greater than the $\Sigma N_{\mathrm{Ru}-\mathrm{i}}$ value $(Q=1.24$; see Table 4), ${ }^{33}$ indicates that the PtRu nanoparticles were in the form of "core-shell" nanoclusters, most likely with Pt in the inner core and $\mathrm{Ru}$ on the outer shell.

The electrocatalytic activity of the Pt-CMM and PtRuCMMs catalysts during methanol oxidation reaction was evaluated by $\mathrm{CV}$ measurements under $1.0 \mathrm{M} \mathrm{CH}_{3} \mathrm{OH}$ and $0.5 \mathrm{M} \mathrm{H}_{2} \mathrm{SO}_{4}$ at room temperature (see the Supporting Information, Figure S6). For the purpose of discussion, Figure 4 displays only the resultant cyclic voltammograms for various catalysts over a selected region under the operating potential region of $0.1-0.6 \mathrm{~V}$. The potential peak at ca. $0.6 \mathrm{~V}$ during the forward scan is normally attributed

(30) (a) McBreen, J.; Mukerjee, S. J. Electrochem. Soc. 1995, 142, 3399. (b) Nashner, M. S.; Frenkel, A. I.; Adler, D. L.; Shapley, J. R.; Nuzzo, R. G. J. Am. Chem. Soc. 1997, 119, 7760.

(31) (a) Chen, J. M.; Sarma, L. S.; Chen, C. H.; Cheng, M. Y.; Shih, S. C.; Wang, G. R.; Liu, D. G.; Lee, J. F.; Tang, M. T.; Hwang, B. J. J. Power Sources 2006, 159, 29. (b) Sarma, L. S.; Chen, C. H.; Wang, G. R.; Hsueh, K. L.; Huang, C. P.; Sheu, H. S.; Liu, D. G.; Lee, J. F.; Hwang, B. J. J. Power Sources 2007, 167, 358.

(32) (a) Hwang, B. J.; Sarma, L. S.; Chen, J. M.; Chen, C. H.; Shih, S. C.; Wang, G. R.; Liu, D. G.; Lee, J. F.; Tang, M. T. J. Am. Chem. Soc. 2005, 127, 11140. (b) Hwang, B. J.; Chen, C. H.; Sarma, L. S.; Chen, J. M.; Shih, S. C.; Wang, G. R.; Tang, M. T.; Liu, D. G.; Lee, J. F. J. Phys. Chem. B 2006, 110, 6475.

(33) Hwang, B. J.; Sarma, L. S.; Wang, G. R.; Chen, C. H.; Liu, D. G.; Sheu, H. S.; Lee, J. F. Chem. Eur. J. 2007, 13, 6255.

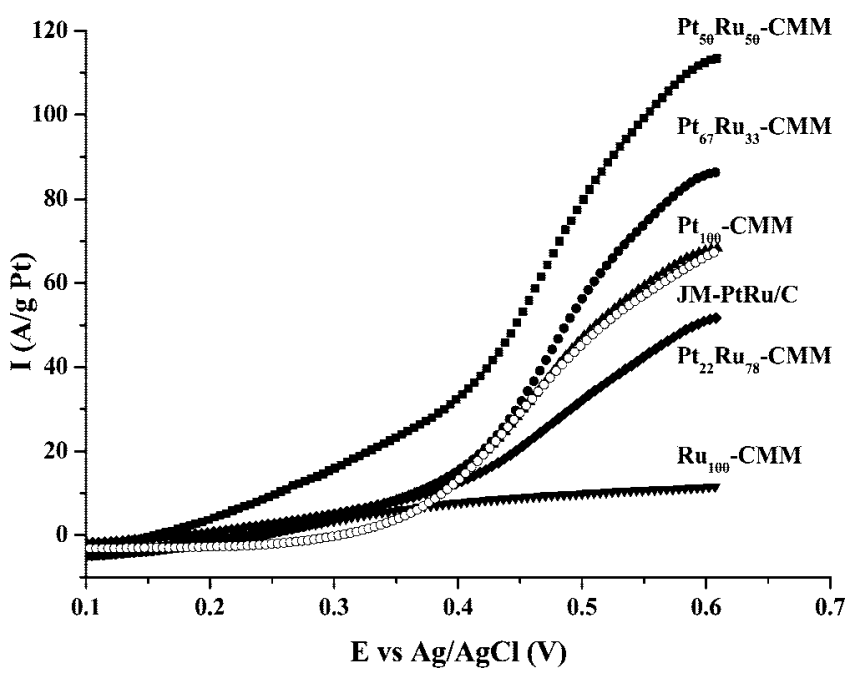

Figure 4. Cyclic voltammograms (forward scans) of methanol oxidation for various PtRu-CMM and JM-PtRu/C catalysts.

Table 5. Electrochemical Performances of Methanol Oxidation for Various PtRu-CMM and the JM-PtRu/C Catalysts

\begin{tabular}{lccc}
\hline \multicolumn{1}{c}{ sample } & $\begin{array}{c}\text { onset } \\
\text { potential }(\mathrm{V})\end{array}$ & $\begin{array}{c}\text { anodic peak } \\
\text { potential }(\mathrm{V})\end{array}$ & $I_{\mathrm{f}} / I_{\mathrm{r}}$ ratio \\
\hline $\mathrm{Pt}_{100}$-CMM & 0.32 & 0.62 & 3.0 \\
$\mathrm{Pt}_{67} \mathrm{Ru}_{33}-\mathrm{CMM}$ & 0.30 & 0.61 & 2.9 \\
$\mathrm{Pt}_{50} \mathrm{Ru}_{50}-\mathrm{CMM}$ & 0.16 & 0.60 & 4.0 \\
$\mathrm{Pt}_{22} \mathrm{Ru}_{78}-\mathrm{CMM}$ & 0.35 & 0.60 & 3.4 \\
$\mathrm{Ru}_{100}-\mathrm{CMM}$ & & & \\
$\mathrm{JM}-\mathrm{PtRu} / \mathrm{C}$ & 0.21 & 0.71 & 2.8
\end{tabular}

to catalytic activity during methanol oxidation, whereas the onset near $0.3-0.4 \mathrm{~V}$ during the reverse scan represents the effectiveness in removing the incompletely oxidized carbonaceous species formed during the oxidation reaction. ${ }^{28,34}$ Accordingly, the electrocatalytic performance of various $\mathrm{PtRu}-\mathrm{CMMs}$ catalysts with various $\mathrm{Pt} / \mathrm{Ru}$ loading was examined and the CV test results are depicted in Table 5. An onset potential for $\mathrm{Pt}_{100}$-CMM was measured at $0.32 \mathrm{~V}$. Upon introducing the Ru metal, a gradual decrease in onset potential with increasing Ru content was observed. However, as the atomic ratio of Ru exceeds ca. 50\%, a subtle increase in onset potential was observed. Among the PtRu-CMM catalysts prepared and examined, the $\mathrm{Pt}_{50} \mathrm{Ru}_{50}$-CMM sample was found to have the lowest onset potential $(0.16 \mathrm{~V})$, which is also less than that of the commercial JM-PtRu/C catalyst $(0.21 \mathrm{~V})$. A similar conclusion can be drawn for the observed anodic peak potential.

In terms of the anodic peak current density measured at the forward $\left(I_{\mathrm{f}}\right)$ and reverse $\left(I_{\mathrm{r}}\right)$ scans of the CV curves, the $I_{\mathrm{f}} / I_{r}$ ratio obtained for the $\mathrm{Pt}_{100}-\mathrm{CMM}$ (3.0) was found to be comparable to that of the commercial JM-PtRu/C catalyst (2.8), indicating that the PtRu-CMM catalysts fabricated by this direct replicated synthesis strategy, namely, by cofeeding the primary carbon sources (FA and TMB) and organometallic precursors $\left(\mathrm{Pt}(\mathrm{acac})_{2}\right.$ and/or $\left.\mathrm{Ru}(\mathrm{acac})_{3}\right)$ using SBA-15 as the template, are less vulnerable to coking by carbonaceous deposits ${ }^{20,34 \mathrm{a}}$ and more tolerant toward $\mathrm{CO}$ poisoning compared to the commercial catalyst, even without the

(34) (a) Huang, J. C.; Liu, Z. L.; He, C. B.; Gan, L. M. J. Phys. Chem. B 2005, 109, 16644. (b) Gu, Y. J.; Wong, W. T. Langmuir 2006, 22, 11447. 


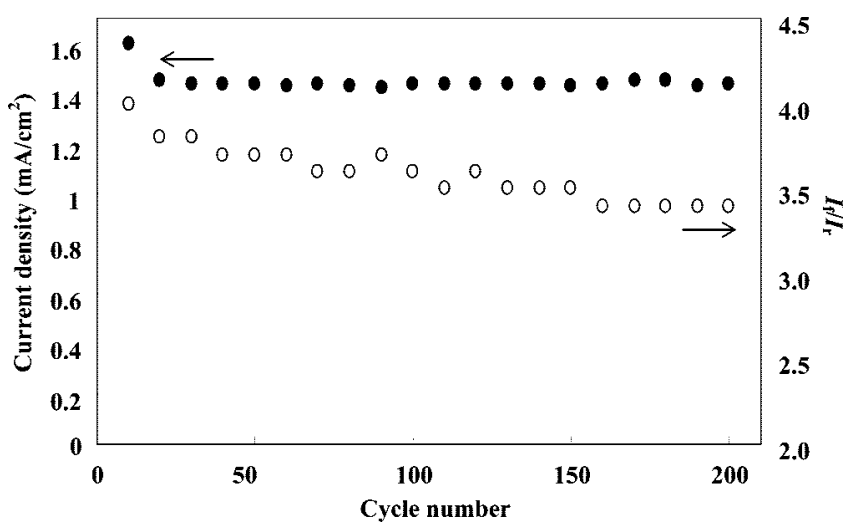

Figure 5. Stability of the $\mathrm{Pt}_{50} \mathrm{Ru}_{50}$-CMM catalyst during methanol electrooxidation.

presence of $\mathrm{Ru}$. Among them, the bifunctional $\mathrm{Pt}_{50} \mathrm{Ru}_{50^{-}}$ CMM catalyst, having the highest $I_{\mathrm{f}} / I_{\mathrm{r}}$ value, exhibits the best electrocatalytic activity. It is noted that, unlike the commercial JM-PtRu/C catalyst (20 wt \% Pt; 10 wt \% Ru), the PtRu-CMMs catalysts reported herein contain only ca. 8 wt $\% \mathrm{Pt}$ and 2-14 wt \% Ru (Table 1). Thus, in terms of the production cost and the mass activity of the PtRu catalyst, $\mathrm{PtRu}-\mathrm{CMMs}$ are far superior than JM-PtRu/C.

The electrocatalytic stability of the $\mathrm{Pt}_{50} \mathrm{Ru}_{50}-\mathrm{CMM}$ catalyst was evaluated by repeated $\mathrm{CV}$ tests (scans) performed using $0.5 \mathrm{M} \mathrm{H}_{2} \mathrm{SO}_{4}$ with $1 \mathrm{M} \mathrm{CH}_{3} \mathrm{OH}$ at room temperature. ${ }^{6,35}$ Up to 200 scan cycles of 3 min each were examined. As shown in Figure 5, a nearly constant peak current density (measured at $0.60 \mathrm{~V}$ vs $\mathrm{Ag} / \mathrm{AgCl}$ ) of the electrooxidation of methanol accompanied by only a slight variation in $\mathrm{I}_{\mathrm{f}} / \mathrm{I}_{\mathrm{r}}$ ratio was observed for $\mathrm{Pt}_{50} \mathrm{Ru}_{50}$-CMM over the total scanned

(35) Zhao, D.; Xu, B. Q. Angew. Chem., Int. Ed. 2006, 45, 4955. period of ca. $10 \mathrm{~h}$, indicating that the catalyst indeed possesses a stable electrocatalytic activity for the oxidation of methanol.

\section{Conclusions}

The novel bifunctional PtRu-CMM catalysts reported herein possess stable alloyed PtRu nanoparticles $(2-3 \mathrm{~nm})$ well-dispersed in ordered mesoporous carbon with high surface area and regular pore channels, which facilitate reactant/product diffusion. Furthermore, these PtRu-CMM catalysts, fabricated by a novel direct replication method using mesoporous silica as template and by cofeeding carbon sources and metal precursors during synthesis, were found to have superior electrocatalytic properties and stabilities compared to common commercial catalysts during the oxidation of methanol. Thus, the supported PtRu-CMM catalysts so fabricated should render future practical and costeffective applications in hydrogen-energy related areas, for example, as electrodecatalysts for PEMFCs and DMFCs.

Acknowledgment. The support of this work by the National Science Council, Taiwan (NSC95-2113-M-001-040-MY3) and by the Academia Sinica Research Project on Nano Science and Technology are gratefully acknowledged. The authors thank Mr. Ding-Goa Liu and Dr. Jyh-Fu Lee (National Synchrotron Radiation Research Center, Taiwan) for their assistance and helpful discussions on the X-ray absorption measurements.

Supporting Information Available: $\mathrm{N}_{2}$ adsorption/desorption measurements, additional TEM, XPS, EXAFS, and CV results (PDF). This information is available free of charge via the Internet at http://pubs.acs.org.

CM702777J 